\title{
Innovative Activities of SMEs in Russia: Constraints and Growth Factors
}

\author{
Submitted 20/08/19, 1st revision 27/09/19, 2nd revision 20/11/19, accepted 18/12/19
}

\begin{abstract}
Dubrova T.A. ${ }^{1}$, Ermolina A.A., ${ }^{2}$ Esenin M.A. ${ }^{3}$
Abstract:

Puprose: The article is aimed at comprehensive study of small enterprises' innovative activity in Russia and highlights the key constraints factors as well as factors promoting small business innovative activity.

Design/Methodology/Approach: We conduct a review of modern domestic and foreign studies on innovative development of SMEs their components and factors to give a comparative description of the innovation activity of SMEs in Russia and the EU countries. We also consider the factors of innovation activity of SMEs in Russia, to identify their regional differences, and to determine the prospects for the innovation activity of small businesses in Russia. The methodological approach is based on the exploration analysis procedures, principal component analysis (PCA), multidimentional classification and logicitic regression. Findings: This analysis revealed that Russian small enterprises are characterized by lower indicators of innovation activity than in many developed countries. The constraints to the growth of the innovation activity of small businesses in Russia are the insufficient level of development of credit financing and the backlog of the production and technological bases.

Practical implications: This approach could be used in the development of promotion measures for new innovative process participants, taking into account the regional context.

Originality/Value: The main contribution of this study is that the approach can be used in the course of the study to confirm regional differences in the innovative development of small enterprises and allows to identify three clusters with different indicators of the innovative activity of small businesses.
\end{abstract}

Keywords: SMEs, innovation activity, Russian regions.

JEL Code: O18, O30.

Paper type: Research article: Growth and Innovation.

Acknowledgment:

The research was supported by Russian Foundation for Basic Research (project № 18-01000960).

\footnotetext{
${ }^{l}$ Doctor of Science (Economics), Professor, Plekhanov Russian University of Economics, National Research University Higher School of Economics, dokladt@ mail.ru

${ }^{2} J u n i o r$ Researcher, National Research University Higher School of Economics, PhD

student, Plekhanov Russian University of Economics, aaermolina@yandex.ru

${ }^{3}$ Candidate of Science (Economics), Associate Professor, Plekhanov Russian University of

Economics, National Research University Higher School of Economics, mikhailesenin@yandex.ru
} 


\section{Introduction}

The promotion of business innovative activity is the relevant topic for developing as well as for developed countries. European Innovation Council (EIC) pilot provides the support of small enterprises and self-employed individuals in the European Union. In Canada, Strategic Innovation Fund invest into innovative business. Besides, there are special programs for self-employed individuals, such as Innovative Supercluster Initiative aimed at the development of successful clusters of scientific institutions, non-commercial organizations, business, etc., (IC, 2018).

The growth of business innovative activity is a strategic goal of the Russian Federation development since it is on the national goals and strategic objectives of the Russian Federation development for the period up to 2024. The promotion of small and medium-sized enterprises (SMEs) innovative activity that may contribute to the increase of national products' competitiveness at the global market plays a crucial role (The Strategy of SME development in the Russian Federation for the period up to 2030, 2016).

The low SMEs innovative activity in Russia and the lack of its involvement in cooperation with other organizations and institutions are marked as the weaknesses of Russia's innovative development in international innovation indexes (SummaryInnovationIndex, SII) (Hollanders and Es-Sadki, 2017a). Besides, the credits availability for business, low investment activity that influances the enterprises innovative activity output are noted in the Global Innovation Index 2018 (Dutta et al., 2018; Havlicek et al., 2013; Breckova and Havlicek, 2013; Breckova, 2018).

Inadequate Russian SMEs innovative activity can be partly explained by their small contribution to the main economic indicators. In the European Union, SMEs are up to $99 \%$ of all non-financial business sector enterprises, their proportion in the total employed population equals $1 / 3$, while in the total value added it has reached almost $40 \%$ in 2016 (Muller et al., 2017). In Russia, SME provides $21.2 \%$ of GDP only for the same period. In 2015, their proportion in the total employed population was equal to $25.6 \%$. According to the Strategy of SME development in the Russian Federation for the period up to 2030, this value is planned to increase to $35 \%$ by 2030. Besides, the strategy is emphasized on the small contribution of SMEs to fixed assets (5-6\% of their total value) and investments in fixed assets (6-7\% of the total investments in fixed assets).

SMEs may become active participants of innovative processes in Russia in case of creating favourable conditions to realize their potential. Alongside with the supporting measures for 'mass' enterprises, a considerable attention is paid to the enterprises that contribute to the improvement of industry structure, technological modernization, innovations (in the strategy of SME development in the Russian Federation for the period up to 2030). The strategy notes the need to implement target supporting 
measures for small businesses in general as well as for their innovative activities due to substantial territorial differences in socio-economic development.

Thus, the comparison of small enterprises' innovative activity in Russia and in the EU countries with a high level of business development represents a primary task in the context of mentioned above priorities of Russia's development. The substantial regional differences determine the importance of the investigation of small enterprises' innovative activity conditions and factors not only at the macrolevel but also at the regional level. The obtaining of regional groups that are different by the features of small enterprises innovative activity is of particular importance for further adaptation of supporting measures to regional specifics.

This research represents the system approach to the analysis of small innovative enterprises and factors constraining the small business innovative activities' development. The paper has the following structure. Section 2 provides the overview of previous studies on innovation development and its components and factors. Section 3 describes the applied methodology and data. Section 4 presents the comparative analysis of small enterprises' innovative activity in Russia and the EU countries. Section 5 focuses on the factors of small enterprises' innovative activity in Russia as well as on regional differences. Finally, section 6 summarizes the main fundings.

\section{Literature Review}

The questions of territorial innovation development and innovation policy have received a great deal of attention in many developed and developing countries. The priority of innovation development is recognized at the national and international level, documented in the development strategies of countries and regions. Over the past decades there has been extensive experience in monitoring and evaluating territorial innovation development. The level of countries and regions' innovation development has been estimated by various international organizations such as World Economic Forum, World Bank, UN, OECD, European Commissin and others.

The separate group of these estimates combines the innovation development indexes designed for international comparisons as well as for monitoring situation in innovation sphere in a particular country (region). The most well-known international indexes of innovation development are the Global Innovation Index (GII), covering more than 100 countries, and the Summary Innovation Index (SII), calculated for the EU countries and several non-european countries (Dutta et al., 2018; Hollanders and Es-Sadki, 2017a). The examples of regional innovation indexes are regional Innovation Index (RII), created in line with SII for the EU regions, and the US innovation index (Hollanders and Es-Sadki, 2017b; Slaper et al., 2016). In Russia regional innovation indexes have recently appeared such as the Russian regional innovation index of Higher School of Economics, the ranking of innovative Russian 
regions of AIRR (Association of Innovative Regions of Russia) (Abrahmanova et al., 2017; The ranking of innovative Russian regions, 2018).

Russia's position in international innovation indexes reflects the unrealized potential in innovation sphere. In GII 2018 and SII 2016 Russia is behind the majority of developed countries. The main constraints to the growth of innovation development level are poor investment climate, underdeveloped infrastructure, insufficient availability of credit market for business, low SMEs innovative activity, the lack of cooperation links in innovative activity (Dutta et al., 2018; Hollanders and Es-Sadki, 2017a; Rupeika-Apoga and Solovjova, 2016). The above regional rankings show that Russian regions are characterized by substantial territorial differences by the level of innovation development, including in small businesses. Moderate and even low innovation development is typical for the majority of the regions and only a small group of Russian regions such as Moscow, St. Petersburg and the Republic of Tatarstan have the indicators of innovation development comparable with some developed countries.

In developed countries a considerable attention is paid to the analysis of innovation development conditions and determinants. A particular focus of the research is the factors of SME innovative activity. For example, it was revealed in the number of countries that SMEs cooperation with other organizations (suppliers, clients, etc.) promotes business innovative activity (De Propis, 2002; Gronum et al., 2012; Lee et al., 2010; Najib and Kiminami, 2011). Earlier empirical research also confirms the positive correlation between the level of ICT development and business activity in innovation sphere (Consoli, 2012). The inflow of highly qualified specialists as well as educating programs for staff promote innovation creation in organizations (Chesbrough, 2007; Rogers, 2004; Dasanayaka and Sardana, 2015).

In Russia, the determinants of small enterprises' innovative activity, the constraints to its growth remain understudied at the present time. The potential of statisitical methods seems to be weakly realized in this research area.

\section{Methodology}

The research of small enterprises' innovative activity in European countries is based on the Community Innovation Survey (CIS, 2016) and national statistical databases (DST, 2018). The data of Federal Statistical Service (Rosstat) (GKS, 2018) are used for the analysis of small enterprises' innovative activity in Russia. Rosstat survey conducted every two years contains the sample of small industrial enterprises and is focused on technological innovations. To obtain factors influencing the innovative processes of small enterpreneurship, the regional statistics of 2015-2017 are applied as well as the data of Unified Information and Analytical Website of State Support for Innovative Business Development. The methodological approach is based on the following econometric methods: the exploration analysis procedures, principal component analysis (PCA), multidimentional classification and logicitic regression. 
To obtain groups of Russian regions with similar features of small enterprises ‘ innovative activity, we move from initial variables to generalized factors calculated by the method of PCA with 'Varimax' rotation. This step provides more than double dimension reduction and transition to ortogonal variable space that is crucial for further classification of the regions. The multidimentional classification is based on the obtained factors with weighted Euclidean metrics. The calculated weights depend on the share of explained dispersion. To robustness check of the obtained classification we compare the results for 2015 and 2017.

It is important to note that using box-plots at the stage of exploration analysis we find out typical observations which are excluded from further classification. These observations are regions with the values of the analyzed variables that are removed from the $1^{\text {st }}$ and the $3^{\text {rd }}$ quartiles by more than 3 interquartile ranges.

To obtain factors significantly influencing the level of small enterprises' innovative activity development in Russian regions the methods of logistic regression are applied. The constructed model allows to estimate the probability of higher than the sample average level of small enterprises' innovative activity development in particular regions depending on their socio-economic characteristics. The training samples are formed on the basis of general characteristic of small enterprises' innovative activity development level in the regions calculated by PCA.

\section{Small Enterprises' Innovative Activity in the European Union and Russia}

Rather high level of innovative activity is typical for European SMEs. According to CIS 2016, almost half (46,4\%) of SMEs in EU-28 implements any type of innovation. The proportion of small innovative enterprises reaches $64,5 \%$ in Portugal, 64,2\% in Belguim (CIS, 2014). It is important to note that various types of innovations (product, process, marketing, organizational) are widespread among European small enterprises (Figure 1).

Figure 1. The proportion of small innovative enterprises in the EU countries, by the types of innovations(CIS, 2016)

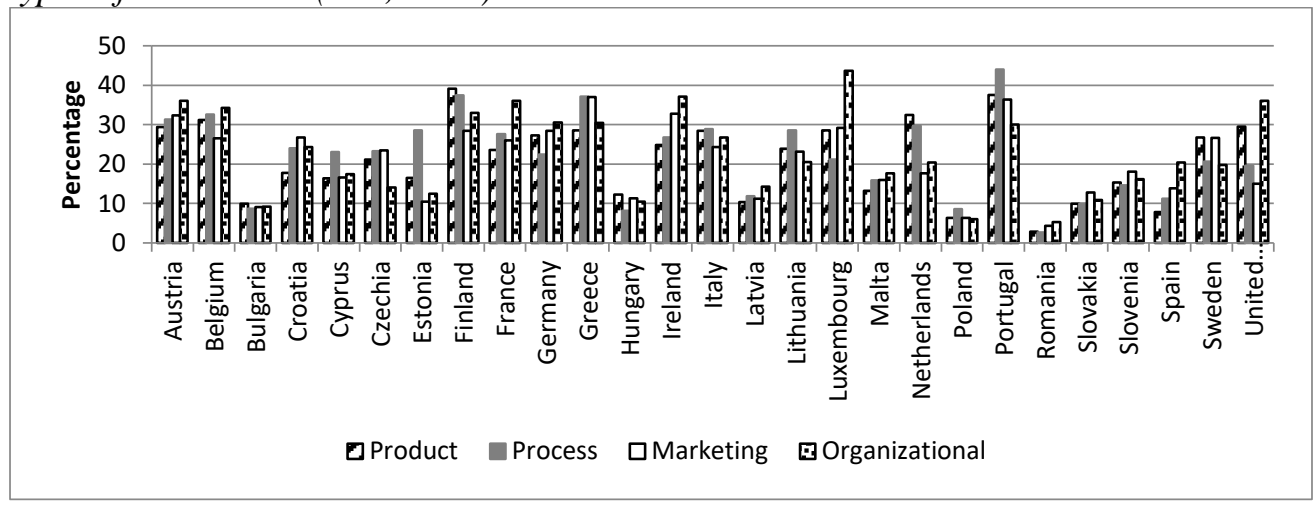


For example, in 2016, in Denmark small enterprises realize organizational and marketing innovation more often than product and process ones $(26.6 \%, 26.4 \%$, $19.0 \%$ and $18.5 \%$ correspondingly) (DST, 2018). In Slovakia and Croatia marketing innovations are the most prevalent. Organizational innovations are more common in Luxembourg, the UK, Ireland and some other countries. The Netherlands and Finland are characterized by the prevalence of product innovations while Cyprus, Lithuania and Portugal demonstrate high share of process innovations (CIS, 2016).

Among various economic activities the highest level of small enterprises innovative activity in the EU is typical for information and communication sphere. It reaches 8083\% (Austria and Belgium) (CIS, 2016). More importantly, rather high proportion of small innovative enterprises is also observed in other ecomomic activities: industry, financial and insurance activities, transportation and storage (Figure 2). The feature of European small enterprises is the prevalence of cooperation in innovative activity, especially in Western and Norhtern Europe. The proportion of small enterprises implementing product innovations in cooperation with other organizations in total number of small enterprises with product innovations is closed to $30 \%$ in Germany, Belgium, Austria.

Figure 2. The proportion of small innovative enterprises in the EU countries, by the aggregated ecomomic activities (CIS, 2016)

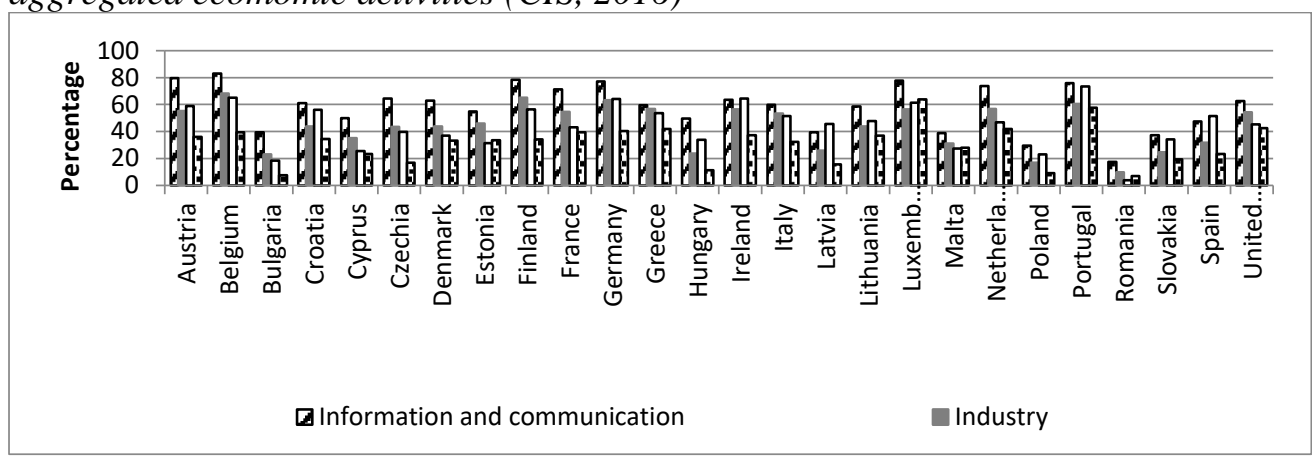

In the European Union, innovation goods and services have a substantial share in small enterprises turnover (in 2016, 24-25\% in Lithuania and Croatia, more than $30 \%$ in Belgium, Spain and other countries). Besides, in many countries, the proportion of new-to-market goods in total turnover of small enterprises is rather high (up to $40 \%$ in Malta). It means that the output of European small innovative enterpises is characterized by high degree of novelty which provides small business competitiveness at the global market. The CIS results show that small enterprises regard innovation production as the strategy to increase turnover, cut costs, expand market share.

The structure of expenditures on small enterprises product and/or process innovations varies substantially across the EU-28 countries. In Eastern and Southern Europe its 
main part is spent on equipment and software while in Northern Europe, Denmark, Finland, Spain it is directed to R\&D (in 2016, more than 60\%).

In the European Union, the main constraint to small enterprises' innovative activity is the high cost of innovative activity, especially in Southern European countries. Financial constraints are less widespread except Cyprus, Greece and Slovenia where the lack of own financial resources was mentioned by $38,2 \%, 38,5 \%$ and $42,8 \%$ of small innovative enterprises correspondingly in 2016. Other constraints are high competitiveness in the market (25-27\% of small innovative enterprises in Portugal and Croatia), the demand uncertainty (25-28\% in Italy and Lithuania), the lack of ideas for innovations and the lack of high-qualified specialists.

In Russia, small enterprises' innovative activity is quite low. In 2017 , only $5.2 \%$ of observed small industrial enterprises have technological innovations. A slightly higher level of innovative activity is observed in manufacturing (5.8\%). It is substantially higher in high-tech and medium-tech level economic activities. In 2015, the proportion of small innovative enterprises reaches $15.0 \%$ in high-tech economic activities with the average level of innovative activity of $4.5 \%$ for small industrial enterprises as a whole (GKS, 2018).

Unlike European countries in Russia small enterprises implement marketing and organizational innovations much less often than technological ones. Meanwhile, these types of innovations frequently open new markets for business, optimize production processes increasing enterprise competitiveness (Dubrova et al., 2014). Another specific feature of Russian small enterprises is innovations' implementation on their own (in 2017 almost two thirds of small industrial enterprises with completed technological innovations). Cooperation in innovative activity is narrow spread. In 2017 , only $14.3 \%$ of small industrial enterprises developed innovations in cooperation with other organizations (GKS, 2018). The perspective way to increase small business innovative activity in Russia is cooperation development of small enterprises with medium-sized and large enterprises, scientific organizations, etc.

Innovation output has a small share in total output of small enterpises (1.6\% in 2017). Like the level of innovative activity, the share of innovation output is somewhat higher for small manufacturing enterprises. Innovation goods and services of small enterpises are characterized by low degree of novelty. In 2017, only $2.1 \%$ of small industrial enterprises innovation output is new to the world market.

Low innovative activity of Russian small enterprises, poor competitiveness of their production are largely explained by the existing constraints for business development, including innovation development. The surveys of Russian Union of Industrialists and Enterpreneurs of 2011 and 2016 show that difficulties with financial resources (both own and credit) take leading positions in the list of constraints for business innovative activity. In 2016, the deficit of own financial resources was reported by more than half enterpreneurs, the difficulties with credit availability are mentioned by $25.6 \%$ of 
respondents (The report "On the business climate in Russia in 2016", 2017, pp. 104106). The main source of finance for small industrial enterprises' innovative activity is their own resources (59.5\% in 2017). Less than one fourth of total expenditures on technological innovations are financed by credits and loans (Figure 3).

Figure 3. The structure of small industrial enterprises expenditures on technological innovations, by the source of financing, in Russia, 2017, \%

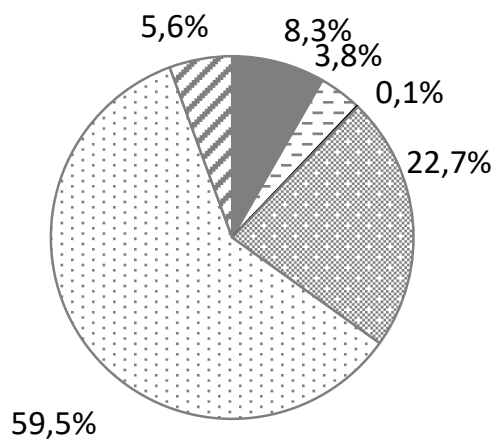

Budget

$\square$ Support funds

- Foreign investments

Credits and loans

$\square$ Small enterprises

According to the surveys of Russian Union of Industrialists and Enterpreneurs of 2007 and 2016, over the past decade enterprises used to report the difficulties with credit availability more often ( $14.9 \%$ vs. $23.4 \%$ correspindingly). Moreover, in 2017, two thirds of organizations did not apply for a loan because $63 \%$ of them relied on their own finances, $7 \%$ reported high interest rate, $2 \%$ did not trust credit organizations (NAFI, 2017). Thus, the access of small business to external financial resources (credits, grants, etc.) is a perpective way of innovative activity promotion in Russia.

Another significant constraint to small industrial enterpises' innovative activity is the high depreciation of their production and technological capabilities. According to Rosstat estimates for 2016, the main goal of investment in fixed assets is the replacement of old equipment (22\% of respondents). The completed survey on small and medium-sized enterpreneurship conducted by Rosstat in 2015 shows that the fixed assets depreciation rate reaches $44-47 \%$ for small enterprises in manufacture of machinery and equipment, paper and paper products, rubber and plastic products, electrical, electronic and optical equipment (Table 1). It is even higher for machinery and equipment, and vehicles. At the same time, the depreciation rate of fixed assets is usually less than 20-25\% in developed countries (Makoveev and Gubanova, 2015).

The main kind of innovative activity in the structure of small industrial enterpises expenditures on technological innovations is equipment purchase (42\% in 2017). R\&D take less than one third of total expenditures on technological innovations (Figure 4). 
Table 1. The dergree of depreciation of fixed assets for small manufacturing enterprises, 2015 , \%

\begin{tabular}{|l|l|l|}
\hline \multirow{2}{*}{ Types of economic activity } & \multicolumn{2}{|l|}{$\begin{array}{l}\text { The degree of } \\
\text { depreciation }\end{array}$} \\
\cline { 2 - 3 } & $\begin{array}{l}\text { all fixed } \\
\text { assets }\end{array}$ & $\begin{array}{l}\text { machinery, } \\
\text { equipment, } \\
\text { vehicles }\end{array}$ \\
\hline Manufacturing & 40.9 & 46.3 \\
\hline Manufacture of food products, including beverages, and tobacco & 40.1 & 44.7 \\
\hline Manufacture of textiles and textile products & 41.1 & 47.1 \\
\hline Manufacture of leather, leather products and footwear & 39.4 & 45.7 \\
\hline Manufacture of wood and wood products & 38.4 & 41.8 \\
\hline $\begin{array}{l}\text { Manufacture of pulp, paper and paper products: publisihing and } \\
\text { printing }\end{array}$ & 46.8 & 53.7 \\
\hline Manufacture of coke and refined petroleum products & 36.3 & 55.1 \\
\hline Manufacture of chemical products & 40.1 & 47.4 \\
\hline Manufacture of rubber and plastics products & 44.5 & 48.9 \\
\hline Manufacture of other non-metallic mineral products & 36.9 & 41.2 \\
\hline Manufacture of basic metals and fabricated metal products & 37.8 & 42.1 \\
\hline Manufacture of machinery and equipment & 44.2 & 51.5 \\
\hline Manufacture of electrical, electronic and optical equipment & 45.0 & 52.8 \\
\hline Manufacture of transport equipment & 40.4 & 47.4 \\
\hline
\end{tabular}

Source: Federal State Statistics Service.

Figure 4. The structure of small industrial enterprises expenditures on technological innovations, by the kinds of innovative activity, in Russia, 2017, \%

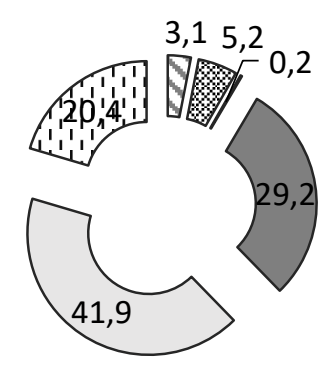

New technologies and software
purchase

Q Design and other developments

- Staff training

$\square R \& D$

In comparison with the EU countries, in Russia the proportion of R\&D in total small enterprises' expenditures on technological innovations is $1.5-2$ times as lower as in Spain, Austria, Finland and Denmark. It means that the perspective way to promote small business' innovative activity in Russia is to develop modernization programs for small enterprises (target preferential credits, collective using of high-tech equipment, leasing, etc.). Thus, insuffient innovative activity of Russian small business is explained, on the one hand, by low level of its development as whole in Russia and, on the other hand, by the existing constraints of small enterprises innovative activity. The most significant are difficulties with credit financing, high 
level of production and technological base and poor cooperation in innovative activity.

\section{The Conditions of SMEs' Innovative Activity in Russian Regions}

The effectiveness of small enterprises supporting measures in innovation sphere depends largely on regional specifics and enterpreneurship conditions. That is why the obtaining of regional segments with similar features of small enterprises innovative activity becomes an increasingly important concern. To answer this research question the multidimensional classification is applied.

The data on 66 and 65 regions correspondingly for 2015 and 2017 are used. There are small innovative enterprises in the selected regions. Other regions without small innovative enterprises are excluded from the analysis. The classification is constructed on the following indicators. The first three variables describe small enterprises" innovative activity ${ }^{4}(\mathrm{x} 1)$, the proprotion of innovation output in total small enterprises output (x2) as well as the proportion of newly implemeted and significantly improved innovation goods and services in total small enterprises output (x3).

Other variables characterize small enterprises" expenditures on technological innovations. The variables $\mathrm{x} 4$ and $\mathrm{x} 5$ represent the contribution of the most significant financial resources: small enterprises ' finances, credits and loans. The variables $x 6$ and $\mathrm{x} 7$ describe the distribution of small enterprises' expenditures on technological innovations by the priority types of innovative activity: R\&D of new goods, services, production processes and methods as well as equipment purchase. Percentage indicators are included in the analysis.

At the step of exploration analysis typical observations are revealed in 2017 (3 regions). These regions are charactarized by higher innovative activity of small enterprises in comparison to other Russian regions (in 2017, it was equaled to $7.7 \%$ and above; the proportion of innovation output in total small enterprises ' output exceeded $7.5 \%$ ).

Using PCA seven initial variables are replaced by three generalized indicators with insignicant loss of information (less than $17 \%$ of dispersion). The first factor characterizes the level of small enterprises' innovative activity development and the novelty of small enterprises innovation goods and services. This factor has high factor loadings on the variables $\mathrm{x} 1-\mathrm{x} 3$. The second factor presents the structure of small enterprises' expenditures on technological innovations including the sources of financing (small enterprises and credit financies). The higher the proportion of credits and loans in the total small enterprises expenditures on technological innovations as well as the lower the proportion of small enterprises finances is, the higher the value of this factor. Finally, the third factor describes the distribution of these expenditures

${ }^{4}$ Technological innovations only. 
by the kinds of innovative activity in Russian regions. The higher the proportion of R\&D and the lower the proportion of equipment purchase are, the higher the value of the third factor.

At the next step, Ward's method is applied to the factors described above. Three clusters that differ by the characteristics of small industrial enterprises innovative activity are obtained. In 2017, the first cluster includes 9 Russian regions with high innovative activity performed by small enterprises. In this cluster the proportion of small industrial innovative enterprises, on average, is $1.6-1.8$ times higher than in other clusters and in the sample as a whole. Also the first cluster is the leader by small enterprises ' innovation output and by the level of innovative goods and services ( $\mathrm{x} 2$ and $\mathrm{x} 3$ ). The feature of this cluster is common use of credit finances for innovation implementation (Figure 5).

Figure 5. The average values of small enterprises innovative activity indicators in the clusters (as a percentage of the sample average values), 2017

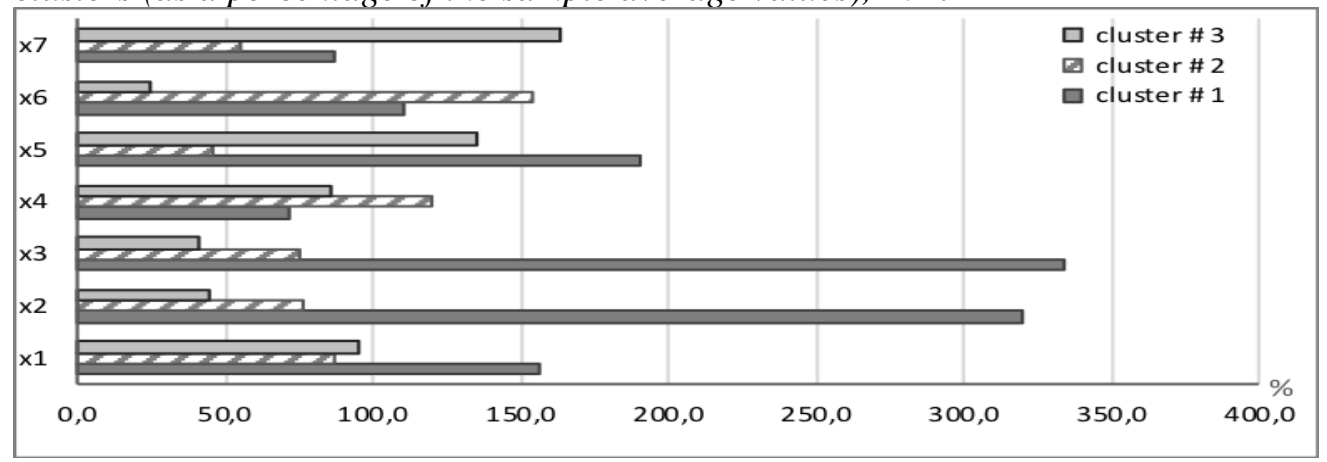

Poor access to credits and loans, their insuffient amount, i.e., on concessional terms, in the combination with steady financial barriers (the lack of finances, high cost of innovation implementation) are substantial constraints to small enterprises ‘ innovative activity in Russia. It is revealed in the second cluster combining 30 Russian regions in 2017. The small enterprises finances mainly determine the resource basis of innovation implementation. The contribution of this source to the total sum of expenditures on technological innovations is almost $3 / 4$ in the second cluster. Overall, the second cluster takes the intermediate position between the first leading cluster and the third cluster by the characteristics of small enterprises' innovative activity (the proportion of innovation output, the degree of its novelty) as presented in Figure 5. The distribution of expenditures on technological innovations indicates the potential of small enterprises' innovative activity development in this cluster. The proportion of expenditures on $\mathrm{R} \& \mathrm{D}(\mathrm{x} 6)$ is rather large while the proportion of expenditures on equipment purchase (x7) is quite low. The last one may denote the appropriate production and technological basis for innovations.

The third cluster demonstrates low level of small enterprises' innovative activity development and high proportion of expenditures on equipment purchase. This points 
out high degree of wear of the existing equipment or its lack in small industrial enterpises in this cluster. In the second quarter of 2018, this constraint was mentioned by every 6th small manufacturing enterprises as well as by $23 \%$ of small enteprises in mining and quarrying (GKS, 2018). Because of the lack of financial, labour and other resources there is a lack of attention toward $R \& D$ of new goods, services, production methods in small enterprises of the third cluster. Besides, low proportion of innovation output (x2) is complemented by low degree of its novelty (x3).

The classification for 2015 also indicates on the existence of three regional clusters. As in 2017, the leading cluster is the smallest by the number of regions. The intermediate cluster consists of 24 regions and this is the largest cluster. 22 regions are belonged to the problem cluster (in 2017, 23 regions). The number of a typical observations is 5 regions. The profiles of these clusters are similar to the classification for 2017 that represents the stability of defined features and problems.

The cluster centers remain the same. However, a part of regions moves to other groups. This shows the dependence of small enterprises innovative activity on economic situation, business climate as well as internal firm factors. The typical regions of the first cluster are the Republic of Tatarstan, Tomsk region, etc. The second cluster includes Tumenskaya oblast', Orlovskaya oblast' and others. Finally, Kirovskaya oblast' and Vladimirskaya oblast' are the examples of the regions of the third cluster.

Thus, the obtained groups of Russian regions have substantial differences in small enterprises' innovative activity development. It means that along with universal supporting measures target regional programs are necessary for small business inclusion in innovative processes.

In this research the logistic regression model is also constructed. This model allows to estimate the probability of being above the sample average level of small enterprises innovative activity development in a particular region. The generalized factor of small enterprises" innovative activity development is calculated by PCA. The generalized factor is transformed into a binary variable where the value „1“ means the level of small enterprises innovative activity development above the sample average and the value, 0 " is the opposite.

As a result, there is the following logistic regression equation (standard errors are below regression coefficients):

$$
\left\{\begin{array}{c}
p=\left(1+e^{-\hat{z}}\right)^{-1} \\
\hat{z}=-47,647+0,241 X_{1}+0,377 X_{2}+0,016 X_{3}+4,041 X_{4}+1,656 X_{5} \\
(13,833) \quad(0,083) \quad(0,120) \quad(0,009) \quad(1,317)
\end{array}\right.
$$

Where: $X_{1}-$ the proportion of high-technology and knowledge-intensive economic activities in GRP, \%; 
$\mathrm{X}_{2}$ - the proportion of organizations, used personal computers, in total number of observed organizations, $\%$;

$\mathrm{X}_{3}$ - the ratio of average per capita monetary incomes to minimum subsistence level in a region, $\%$.

Also this model includes two dummy variables: $\mathrm{X}_{4}$ equals 1 if there is a city (cities) with the population more than 500.000 people in a region and 0 otherwise; $\mathrm{X}_{5}$ equals 1 if there are more than 7 objects of innovation infrastructure per $1 \mathrm{mln}$ labour force population in a region and 0 otherwise.

The number of observations is equaled to 58 regions. Wald's statistic shows the coefficients significance at the level of $\mathrm{p}=0.1$ Corrected $\mathrm{R}^{2}$ equals 0.643 , the proportion of correctly predicted observations is $81.0 \%$ that indicates sufficient model quality.

All indicators included in the model positively influence the probability of above sample average level of small industrial enterprises ' innovative activity development in Russian regions. A large proportion of high-technology and knowledge-intensive economic activities in GRP and the presence of innovation infrastructure objects in a region promote organizations cooperation in innovative activity that contributes to small enterprises inclusion in innovative processes. High income level of the population may influence innovative activity and enterpreneurhsip twofold.

On the one hand, it forms the demand on small enterprises output. On the other hand, start-ups are created among the population. High level of ICT development in a region allows to reduce financial and time costs, to simplify the search of partners and sales markets, to increase labour productivity. All mentioned above create resources and conditions for innovative activity. Finally, cities with the population more than 500.000 people are regional economic centers where business and qualified specialists are concentrated. The complex of human resources and relatively comfortable conditions for enterpreneurship (developed infrastructure, expanded access to suppliers) contributes to business activity, i.e., in innovation sphere. This finding is confirmed in the authors' model.

\section{Conclusion}

This analysis shows that Russian small enterprises are charactarized by lower than in many developed countries indicators of innovative activity. The constraints for small business innovative activity growth in Russia are at insuffient levels in credit finance development, backlog of the production and technological base, poor business cooperation, including state organizations.

The modelling results demonstrate that regional socio-economic conditions significantly influence on small enterprises ' innovative activity. The applied approach confirms regional differences in small enterprises innovation development and allows 
to define three clusters with different indicators of small business innovative activity. It is important to note that the obtained classification in dynamics confirms the regional clusters of „leaders“, „,intermediate regions“ and ,problem regions“ on the basis of analyzed indicators. The results of multidimensional regional classification contribute to the understanding of perspective ways of small innovative enterprises support. Also it can be used in the development of promoting measures for new participants of innovative processes taking into account regional context.

\section{References:}

Abrahmanova, G.I., Bahtin, P.D., Gokhberg, L.M. 2017. The ranking of innovation development of Russian regions. Issue 5, Moscow, Higher School of Economics.

Brecková, P. and Havlícek, K. 2013. Leaders Management and Personnel Controlling in SMEs. European Research Studies Journal, 16 (4), Special Issue on SMEs.

Breckova, P. 2018. Export Patterns of Small and Medium Sized Enterprises. European Research Studies Journal, 21(1), 43-51.

CIS. 2018. Community innovation survey. Available online: https://ec.europa.eu/eurostat/web/microdata/community-innovation-survey

Consoli, D. 2012. Literature analysis on determinant factors and the impact of ICT in SMEs. Procedia - Social and Behavioral Sciences, 62, 93-97.

Dasanayaka, S.W.S.B. and Sardana, D.G. 2015. Development of Small and Medium Enterprises through Clusters and Networking: A Comparative Study of India, Pakistan and Sri Lanka. International Journal of Economics and Business Administration, 3(2), 84-108.

De Propris, L. 2002. Types of innovation and inter-firm co-operation. Entrepreneurship and Regional Development, 14, 337-353.

DST. 2018. Denmark Statistics. Available online: https://www.dst.dk/en

Dubrova, T.A., Esenin, M.A., Ermolina, A.A., Shulaeva, O.V. 2016. Small and mediumsized entrepreneurship: the increasing role in innovative changes of Russian economics. Moscow, "Dashkov and Co", 230.

Dutta, S., Lanvin, B., Wunsch-Vincent, S. 2018. The Global Innovation Index 2018: Energizing the World with Innovation. Cornell University, INSEAD and WIPO.

GKS. 2018. Data on institutional chenges in economy. Available online: http://www.gks.ru/wps/wcm/connect/rosstat_main/rosstat/ru/statistics/enterprise/refor $\mathrm{m} /$

Gronum,S., Verreynne, M.L., Kastelle, T. 2012. The role of networks in small and mediumsized enterprise innovation and firm performance. Journal of Small Business Management, 50, 2, 257-282.

Havlíček, K., Thalassinos. I.E. and Berezkinova, L. 2013. Innovation Management and Controlling in SMEs. European Research Studies Journal, 16(4), 57-70, Special Issue on SMEs.

Hollanders, H., Es-Sadki, N. 2017. European Innovation Scoreboard 2017. EU, MERIT.

Hollanders, H., Es-Sadki, N. 2017. Regional Innovation Scoreboard 2017. EU, MERIT.

Chesbrough, H.W. 2007. Why companies should have open business models. MIT Sloan Management Review, 48(2), 22-28.

IC. 2019. Innovation Canada. Available online: https://www.ic.gc.ca/eic/site/080.nsf/eng/home 
Lee, S., Park, G., Yoon, B., Park, J. 2010. Open innovation in SMEs - An Intermediated network model. Research Policy, 39, 2, 290-300.

Makoveev, V.N., Gubanova, E.S. 2015. Management of innovation manufacturing activities: regional aspect. Vologda, Institute of Socio-Economic Development of Territories of RAS, 166.

Muller, P., Julius, J., Herr, D., Koch, L., Peycheva, V., McKierman, S. 2017. Annual Report on European SMEs 2015/2016: Focus on self-employment. European Commission.

NAFI. 2017. The financial availability for SMEs and the level of financial organizations information openness. The study within the $3^{\text {rd }}$ International conference on financial literacy and financial availability 'How to increase the consumers trust to financial market? Moscow, Analytical Center NAFI, Russian Microfinancial Center, National Association of Microfinancial Center Participants.

Najib, M., Kiminami, A. 2011. Innovation, cooperation and business performance. Some evidence from Indonesian small food processing cluster. Journal of Agribusiness in Developing and Emerging Economies, 1(1), 75-96.

On the national goals and strategic objectives of the Russian Federation development for the period up to 2024. 2018 (Presidental Decree) N. 204 (Rus.)

Rogers, M. 2004. Networks, firm size and innovation. Small Business Economics, 22, 141153.

Rupeika-Apoga, R. and Solovjova, I. 2016. Profiles of SMEs as Borrowers: Case of Latvia. 10.1108/S1569-375920160000098005.

Slaper,T., van der Does, T., Egan, P., Ortuzar, G., Strange, R. 2016. Driving Regional Innovation. The Innovation Index 2.0. U.S. Economic Development Administration, Indiana Business Research Center, Kelley School of Business, Indiana University.

The ranking of innovative Russian regions: 2017 version. 2018. Moscow, AIRR.

The report "On the business climate in Russia in 2016". 2017. Russian Union of Industrialists and Enterpreneurs. Moscow.

The Strategy of SME development in the Russian Federation for the period up to 2030. 2016 (State Order) N. 1083-r (Rus.) 